肝へモジデローシスを合併したェルシニア菌肝膿瘍の 1 例

\author{
焼津市立総合病院外科, *同 内科 \\ **東京大学第 1 外科 \\ ***埼玉医科大学総合医療センター病理
}

北山 丈二 長田 卓也 濱口 正章 小林 亮

大井俊孝位田保之原宏介富山 次郎

市川 紀俊* 津久井 元 ${ }^{* *}$ 糸山 進次***

\title{
A CASE REPORT OF HEPATIC ABSCESSES DUE TO YERSINIA ENTEROCOLITICA ASSOCIATED WITH HEMOSIDEROSIS
}

\section{Joji KITAYAMA, Takuya OSADA, Ryo KOBAYASHI, Masaaki HAMAGUCHI, Toshitaka OHI, Yasuyuki INDEN, Kosuke HARA, Jiro TOMIY AMA, Noritoshi ICHIKAWA* Hajime TSUKUI ${ }^{* *}$ and Shinji ITOYAMA ${ }^{* * *}$}

Department of Surgery and Internal Medicine*, Yaizu Municipal Hospital, The 1st Department of Surgery, Tokyo University School of Medicine**, and Pathology, Saitama Medical School***

索引用語：エルシニア菌, 肝膿煌, 肝へモジデローシス

はじめに

急性胃腸炎の起因菌である Yersinia enterocolitica による肝膿煌はきわめてまれで, 著者らの検索した限 りでは1949年 Hässig らの報告1)以来18例の報告をみ るのみで, 本邦での報告例はない，今回われわれはこ れによる肝膿瘍の 1 例を経験したので, 若干の文献的 考察を加えて報告する。

\section{症例}

患者：37歳, 女性, 農家の主婦。

既往歴：22歳，急性虫垂炎にて虫垂切除。

家族歴：特記すべきことなし。

現病歴：昭和 62 年 3 月下旬上り食欲不振, 全身倦意 感あり，3 月30日昼より39度台の熱発がみられ，翌日 全身紅斑出現したため当院内科受診. 入院後, 画像診 断にて肝に多発性の腫瘤性病変が認められた。経過中 腹痛および明らかな下痢症状は認められなかった。

入院時現症: 身長 $145 \mathrm{~cm}$, 体重 $52 \mathrm{~kg}$, 貧血, 黄疸な し. 体温39.6度, 肝が 1 横指ふれた。

<1988年 7 月 13 日受理 >別刷請求先 : 北山 丈二 厂425焼津市道原 1000 焼津市立総合病院外科

入院時検查所見 : 白血球 $26,200 / \mathrm{mm}^{3}$, 血沈 $12 \mathrm{~mm} /$ $\mathrm{hr}, \mathrm{CRP} 13.6 \mathrm{mg} / \mathrm{dl}$ と高度の资症反応あり, Hb 11.0 $\mathrm{mg} / \mathrm{dl}$ と軽度低色素性貧血, GOT $80 \mathrm{IU} / \mathrm{dl}$, GPT 109 $\mathrm{IU} / \mathrm{dl}$, 血糖值は $254 \mathrm{mg} / \mathrm{dl}$ と高值であった。これにつ

因 la 入院時US：肝内に多数の低吸収域が認めら れた。

因 $1 \mathrm{~b}$ 術中 $\mathrm{T} チ$ チフブ造影：肝内胆管から膿瑒腔が つながって造影されている(失印)。

a

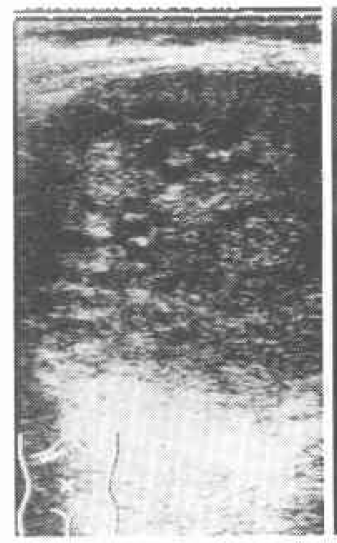

b

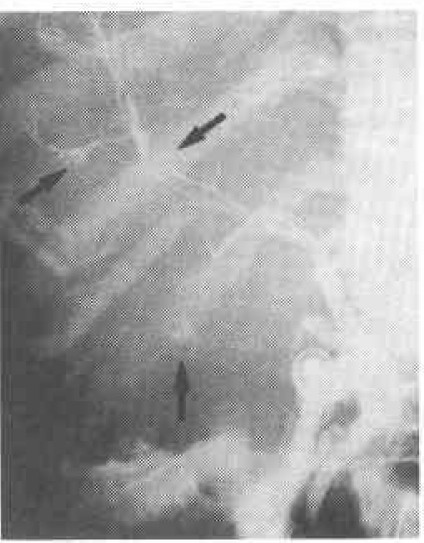


いては術後75gGTT で軽度糖尿病の存在が確認され た.

Ultrasonography（US）：肝全域に表面から内部一 径 $1 \mathrm{~cm}$ 大の低吸収域が重なって存在，モザイク状エ コーを呈した（図1a）。

Computed tomography（CT）：肝はびまん性に腫

図 2 CT スキャン像。(上) 入院時：肝内に無数の低 吸収域が, 蜂巣状に存在した。(下)手術後 7 か月時： 膿笏間の肝実質はやや增加しているが，蜂巣状膿場 腔㳖然残存している。
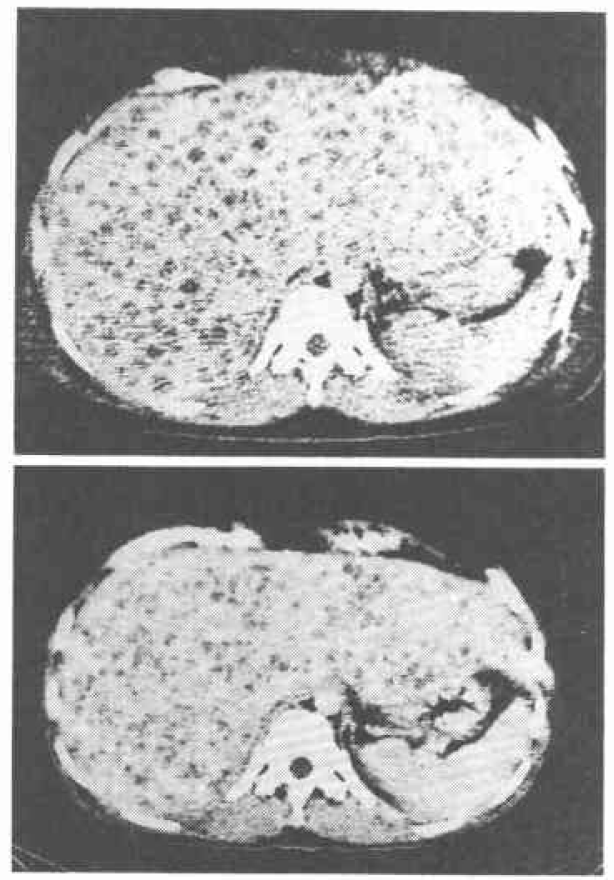

図 3 術中写真. 肝表面に無数の黄白色の結節がみら れた (知)。

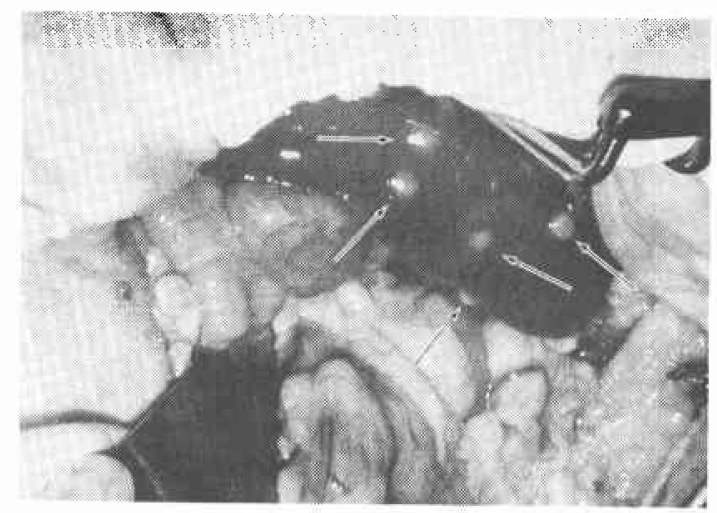

大，肝内に径 $1 \mathrm{~cm}$ 大の粒のそろった境界明瞭な低吸収 域が無数に散在した（図 2 )。

入院後経過：39 40度の弛張熱が 4 日間続き，抗生 剂治療に反応せず，全身状態の悪化もみられたため， 4 月 4 日多発性肝膿煌の診断にて, 腹腔内精査, 可能 ならばドレナージを目的として開腹にふ2きった。

開腹所見：黄色透明の腹水が多量にみられた，肝は やや暗赤色をおび腫大，表面に径 $1 \mathrm{~cm}$ 大の黄白色の柔 らかい結節が多数認められ，多発性肝膿堭が確診され た(図 3 )。胆道采，全腸管を検索したが異常所見は認 められなかった。肝組織とともに膿揚の一部を生検,

腹水之ともに病理細菌学的検查に提出し, 胆道系の精

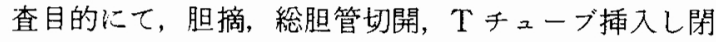
腹した。術中胆道造影では胆道系は末梢をで平滑で十 二指腸への流出も良好, 肝内では膿瘍腔の一部が肝内 胆管からつながって造影された（図 1b).

細菌娭查：入院時動脈血, 手術時腹水, 膿煌部, さ らに術当日夜 Tチューブより採取した胆汁いずれか らも Yersinia enterocolitica が娭出された。

血清娭査：エルシニア抗体価が640倍希积で陽性(正 常20倍以下) と著增していた。

病理組織所見：肝生検組織にて中央に bacterial colony，周囲に炎症細胞の浸潤をともなら腫演がみら れた。強拡大にて球菌状の細菌が密集して存在, グラ 么陰性球桿菌の Yersinia enterocolitica と矛盾しな い像が得られた。交た残存肝組織中に黄褐色の顆粒が 密に沈着, Berlin blue 染色にて青藍に染まりへモジデ

図 4 (左) コロニ一の強挔大 (H.E.染色, $\times 400$ 倍). グラム陰性球桿菌の Yersinia enterocoliticaに矛 盾しない.（右) 残存肝組織部 (Berlin Blue 染色, $\times$ 400倍). 鉄の顆粒が無数に染色されている. 主に肝 細胞内にみられた。

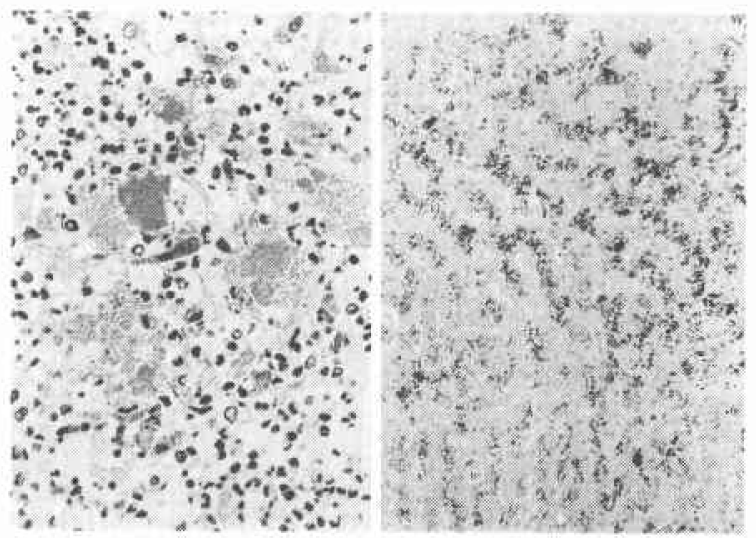


図 5 経過

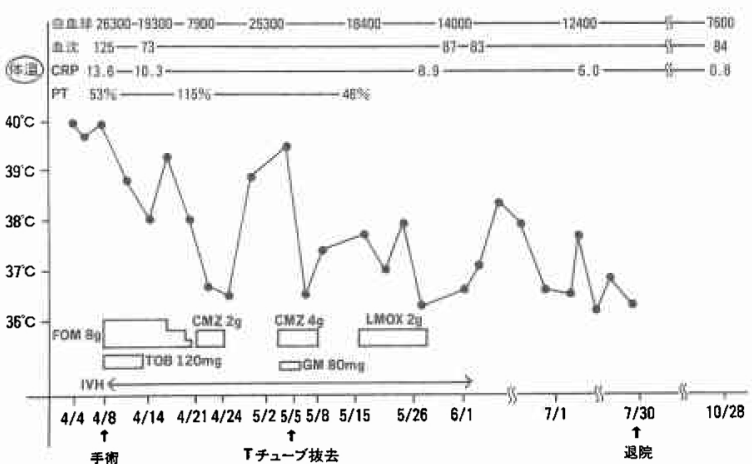

リンと同定され，肝へモジデローシスの併存が診断さ れた（図 4 ).

術後経過：4月 4 日手術施行後, 一過性に解熱, 白 血球と減少傾向をみたが，完治には到らず，何度か熱

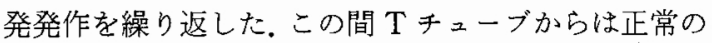
胆汁が流出，胆汁培養でる菌は検出されなかった。 1 か月後 $T$ チューブ抜去, 以後は抗生剂治療と高力口 リー輸液による栄養管理のみにて症状は次第に軽快, 発症後約 4 加月にて退院した，以後外来通院中である が 7 か月後の CT でも依然膿瘍部に相当する低吸収域 が存在している(図 2 )。しかし臨床症状はほとんどで なく日常生活にも全く支障はない。白血球 $7,600 / \mathrm{mm}^{3}$ CRP 陰性之炎症反応も打さまっている（図5）。

\section{考察}

Yersinia enterocolitica はネズミ，ブタなどの動物 からよく検出され，ときにヒトに経口感染し，回腸末 端炎，腸間膜リンパ節炎をおこす，感染例の汪とんど は単発例で，これらの動物との接触が感染の契機とさ れている。この患者も家の中で，ネコとインコを飼っ ておりこれを通して本菌と接触，感染をおこしたので はないかと推測される。近年急性下凩症の便培養にて エルシニア菌が検出された例が多数く報告されてきて おり，急性腸炎の原因として本症は注目をあびてきて いる2).しかし本菌による肝膿瘍例はきわめてまれで われわれの検索した限りでは現在まで18例の報告があ るのみで本邦では報告例はない。このうち10例が死亡 （死亡率56\%)，生存例のほとんどは1970年後半以後の もので，強力な抗生剂治療が効を奏したと考えられる 症例ばかりであった。詳細を検討しえた12例を表 1 に 示す3) 13)，易疲労感，腹痛等で発症することが多く， 下莉および発熱は必ずしも全例にみられなかった，膿

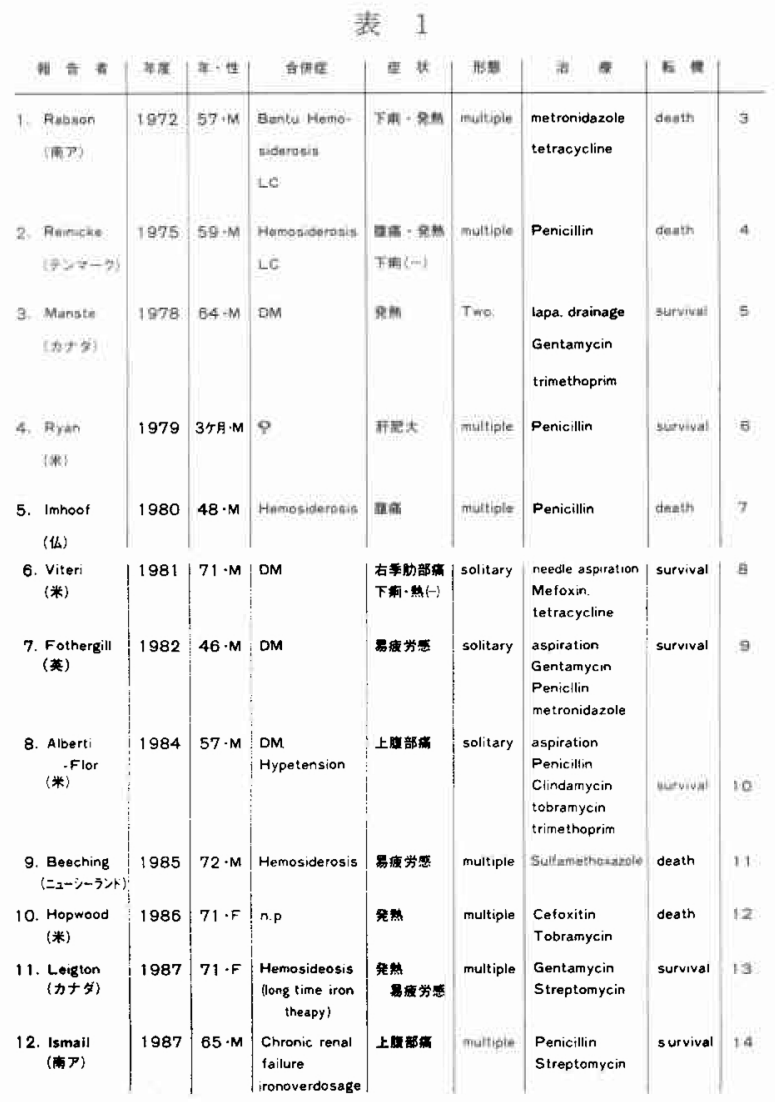

瘍形態は12例中 8 例が多発性， 3 例が孤立性，1例は 肝中央部に径 $4 \mathrm{~cm}$ ののが 2 個認められたもので あった。生存例は 7 例（死亡率 $42 \%$ ）で, ペニシリン 系，マクロライド系, ST 合剤などの混合投与が有効で あると考光られた，多発性のもの以外の 4 例には内科 的治療に加壳，全例外科的ドレナージの処置がなされ た全例生存していた。

また12例中 4 例に糖尿病の合併がみられたはか, 肝 硬変，腎不全などの全身状態の悪化した例に多くみら れた。ささに半数の 6 例が肝のへモジデローシスない しへモクロマトーシスを合併して扣り，本例むまさに これに相当した。近年，鉄は細菌感染の成立に重要な 役割を果たしており，宿主の鉄の過剩状態は細菌の感 染しやすい状態としてとら兄られてきている(5)16). し かもエルシニア菌はその成育を外因性の鉄に強く依存 しているため, へモジデリンの大量に沈着した肝は本 菌の成育に格好の場所ではないかと推測される ${ }^{11) 13)}$. 本症例では血清鉄値も総鉄結合能も低值で，輸血，鉄 の過剰摂取などの既往歴すないため, 肝へモジデロー 
シスの原因は不明であるが，腸咨の前駆症状もないた め, 経口的に入ったエルシニア菌が比較的早い時期に 経胆管的に肝に達し，へモジデリンを利用して活発な 増殖をきたしたのではないかと考えている。

さて孤立性の肝膿場に対して外科的ドレナージが頻 回に行われるのに対し，多発性肝膿煌に対しては従来 より外科的治療は無効とされていた。しかし近年, CT やUSをガイドに可能な限り経皮的にドレナージを施 行し，有効であった例が報告されてきている17).

Brent $ら^{18)}$ は17例の多発性肝膿煌の患者に対し，従 来の内科的治療に加光, 何らかのかたちで外科的ドレ ナージを施行し12例の生存例を得たと報告している. これは従来の多発性肝膿瘍の死亡率50～ $80 \%$ と比べ, 非常に良い成績といえる，本症例では開腹，総胆管切 開し，Tチュープドレナージを試みたが，両葉にわた る無数の小膿瘍であったため, 真の有効なドレナージ とはならず，寛解に約4か月を要し，その治癒機転には 抗生剂治療怙よび自然寛解の要素が強かったと思われ る. しかし術前40度近くの発熱と白血球増多症が一過 性に低下し, 術直後の T千ューブから採取した䏣汁中 からもエルシニア菌が検出されたことから, 手術前の 急性重症期を脱出できたといら点ではドレナージの効 果は一応あったと考えている，以上のことを考虑し， 本症例のような多発性肝膿瘍の重症例で内科的治療に 抵抗性のものに対して, 原発巣の検索という意味も含 め, 積極的に膿瘍ないし感染胆汁の外科的ドレナージ をはかることが有効かと思われた。

$$
\text { おわりに }
$$

37歳, 女性, Yersinia enterocolitica 比る多発性 肝膿瘍で肝へモジデローシスを合併, 抗生剂治療に加 え, 開腹, Tチニーブドレナージを施行し症状の改善 をみた 1 例に若干の対献的考察を加员て報告した。

\section{文献}

1) Hässig A, Karrer J, Pusterla F : Über pseudotuberkurose beim menschen. Schweiz Med Wschr 41 :'971-972, 1949

2）善養寺浩：Yersinia enterocolitica および媯結菌 の菌学, 生態と感染症. 日細菌誌 $30: 571-579$, 1975

3) Rabson AR, Koornhof $\mathrm{HJ}$, Notham $\mathrm{J}$ et al: Hepatic abscesses due to yersinia enterocolitica. Br Med J $11: 341-343,1972$
4) Reinicke V, Korner B : Furminant septisemia cauused by yersinia enterocolitica. Scand $\mathrm{J}$ Infect Dis $9: 249-251,1977$

5) Manste C, West J, Cosman HH : Liver absesses due to yersinia enterocolitica. Can Med Assoc J 119: 922-923, 1978

6) Ryan ME, Burke PJ, Novigen QT : Hepatic abscesses due to yersinia enterocolitica. Am J Dis Chil 133 : 961-962, 1979

7) Imhoof $B$, Auckenthaler $R$ : Septicèmie áYersinia enterocolitica. Schweiz Med Wschr 110 : 1115-1117, 1980

8) Viteri AL, Howard PH, May JL et al: Hepatic abscesses due to Yersinia enterocolitica without bacteremia. Gastroenterology 81 : 592-593, 1981

9) Fothergill J, Mulira AEJL, Skirrow MB: Liver abscess due to an unusual stain of Yersinia enterocolitica. Post Grad Med j 58 : 371-372, 1982

10) Alberti-Flor JJ, Jeffers $L J$, Iscaudari $M$ et al: Successful management of a Yersinia enterocolitica liver abscess. Digestion $29: 250-252$, 1984

11) Beeching NJ, Hart HH, Synek BJ et al: A patient with hemosiderosis and multiple liver abscesses due to Yersinia enterocolitica. Pathology $17: 530-532,1985$

12) Hopwood AH, Riddle BW: Yersinia enterocolitica hepatic abscesses. J Kentucky Med Assoc $20: 13-15,1986$

13) Leighton PM, McSween HM: Yersinea hepatic abscesses subsequent to long-termiron therapy. JAMA $20: 964-965,1987$

14) Ismail MHA, Hodkinson $H J$, Patel $M$ et al : Multiple liver abscesses caused by Yersinia enterocolitica. S Afr Med J $72: 291-292,1987$

15) Finkelstein RA, Sciortino CV, McIntosh MA : Role of irion in microbe-host interactions. Rev Infect Dis $5: 759-777,1983$

16) Ward $C G$ : Influence of iron on infection. Am $J$ Surg $151: 291-295,1986$

17）伊藤文憲, 野口武英, 仲間敏彦湶か：経皮的ドレ ナージと抗生剤の併用により治瘾せしめた多発性 肝膿場の一例. Prog Med 3：1323-1328, 1983

18) Brent WM, Peter D: The diagnosis and treatment of pyogenic liver abscesses. Ann Surg $200: 328-335,1984$ 